\title{
The Optimization of Antibacterial Production Time of Actinomycetes (J4 Isolate) Against Staphylococcus Aureus and Escherichia Coli
}

\author{
Alfian Syarifuddin ${ }^{1}$, Nanik Sulistyani ${ }^{2}$, Ratna Wijayatri ${ }^{3}$ \\ \{naniksulistyani@gmail.com ${ }^{2}$ \} \\ Departement Pharmacy, Faculty of Health Science, Universitas Muhammadiyah Magelang, \\ Indonesia ${ }^{1,3}$ \\ Faculty of Pharmacy, Ahmad Dahlan University, Indonesia ${ }^{2}$
}

\begin{abstract}
There are many cases of antibiotic resistance that cause death in patients infected with bacteria. The increase in cases necessitated the discovery of new antibiotics as an alternative to antibiotics that were already resistant. Bacteria that produce antibiotic compounds are located in the rhizosphere of a plant. One of them is the rhizosphere of the red ginger plant (Zingiber officinale Roscoe var. Rubrum). The bacterial isolate that produces new antibiotic compounds in the rhizosphere of red ginger is Isolate J4. Isolate J4 can produce secondary metabolites in the form of antibiotic compounds after inoculation on Starch Nitrate Broth (SNB) medium and incubated in a few days to obtain optimal antibiotic compounds based on their activity. The purpose of this study was to determine the results of the antibiotic activity of secondary metabolites of isolate $\mathrm{J} 4$ in producing antibiotics against Staphylococcus aureus and Escherichia coli bacteria. Antibiotic activity profile was observed by looking at the relationship between the inhibition zone and the incubation time of these isolates. The results showed that isolate $\mathrm{J} 4$ obtained optimal antibiotic that inhibited the growth of Staphylococcus aureus bacteria after incubation for ten days with an average inhibition zone diameter of $14.2 \mathrm{~mm}$, whereas for Escherichia coli bacteria after incubation for five days which is $12.3 \mathrm{~mm}$ in diameter.
\end{abstract}

Keywords: Actinomycetes, Antibiotic, Isolate J4, Metabolite secondary, Rizosfer

\section{Introduction}

Infectious diseases still rank first in health problems. Infection is a disease caused by a microorganism, including viruses, bacteria, fungi, and protozoa. One of the bacteria that can cause infection is Escherichia coli and Staphylococcus aureus [1]. Escherichia coli often cause infections of the urinary tract, diarrhea, and other diseases [2]. Staphylococcus aureus is an infectious disease-causing bacteria that can primarily cause skin and tissue diseases in the human body [3]. Treatment of these infections using antibacterial drugs. However, this treatment is hampered by cases of antibacterial resistance so that it requires the discovery of new antibacterial drugs. Exploration of new sources of antibacterial is carried out by means of exploration to find the antibacterial-producing microorganisms that these bacteria produce. The most antibacterial producing bacteria are actinomycetes. Actinomycetes are widely researched because they can produce antibacterial, vitamins, and enzymes [4]. The screening process in the process of finding antibacterials consists of two stages, namely primary screening starting from 
isolating the producing source and testing the results of the isolates obtained, and secondary screening, one of which is to find the optimal conditions for the isolate to produce antibacterial from the results of the isolates that have been obtained [5].

Optimization of secondary metabolite production was carried out on the Rhizosphere of the roots of Jatropha (Jatropha Curcas L.) against pathogenic bacteria and the resulting bacterial isolate Actinomycetes IBPT 01 was able to provide activity against 9 pathogenic bacteria. The optimum time for the production of secondary metabolites by the Actinomycetes IBPT 01 bacterial isolate against pathogenic bacteria was different, namely the 4th day, 7th day, 8th day, 9th day and 26th day [6]. Isolate Streptomyces afghaniensis VPTS3-1 isolated from Palk Strait, India performed temperature optimization on Actinomycetes isolates with temperatures of 5, $10,20,30,40$, and $50^{\circ} \mathrm{C}$ for 7 days and got the results at $30^{\circ} \mathrm{C}$ to get an optimal inhibition zone of $20 \mathrm{~mm}$ against P.vulgaris bacteria and the minimum against B.subtilis and optimum against the fungus Helminthosporium oryzae and F. solani [7].

The optimal time for bacterial isolates to produce antibacterials varies widely. Isolate $\mathrm{J} 4$ has not been optimized for the production time of secondary metabolites in the form of antibacterials against Staphylococcus aureus and Escherichia coli. Therefore, this research needs to be done to determine the optimal time of $\mathrm{J} 4$ isolate in producing secondary metabolites so that the time/ day needed for incubation can be produced to get optimal antibacterial production.

\section{Method}

\subsection{Ingredient}

SNB media, Mueller Hinton media, $\mathrm{NaCl} 0.9 \%$, BHI, Mc Farland standard (108 CFU / $\mathrm{mL}$ ), 25\% glycerol, $\mathrm{NaCl}, \mathrm{KNO} 3, \mathrm{~K} 2 \mathrm{HPO} 4, \mathrm{MgSO} 4.7 \mathrm{H} 2 \mathrm{O}, \mathrm{FeSO} 4.7 \mathrm{H} 2 \mathrm{O}$, cork borer, Isolate $\mathrm{J} 4$ from the soil of the red ginger plant (Zingiber officinale Roscoe var. Rubrum).

\subsection{Making a starter culture}

Making the starter is done by taking a quarter of the isolate plate $\mathrm{J} 4$ inserted into $50 \mathrm{~mL}$ sterile SNB media [8]. Incubated at room temperature for 5 days with agitation using a magnetic stirrer at $200 \mathrm{rpm}[9]$.

\subsection{Preparation of fluid test}

A five $\mathrm{mL}$ starter was inserted into the erlenmeyer containing $50 \mathrm{~mL}$ of sterile $\mathrm{SNB}$ media [9]. Incubated at room temperature for 5 days with agitation using a magnetic stirrer. After 5 days, $50 \mathrm{~mL}$ of culture stratified were transferred to erlenmeyer containing $500 \mathrm{~mL}$ of sterile SNB media (1:10) and incubated at room temperature for 14 days. Sampling was done every day as much as $1 \mathrm{~mL}$ and put into eppendorf then labeled and stored in the freezer [10] [11]. 


\subsection{Separation of cell biomass and active substances}

The test culture that has been taken for 14 days is centrifuged at $8000 \mathrm{rpm}$ for 10 minutes at $4^{\circ} \mathrm{C}$ [12] to separate supernatant and sediment. The supernatant containing the active substance is introduced into the new eppendorf.

\subsection{Preparation of bacterial suspensions}

Bacterial stock of $100 \mu \mathrm{L}$ was added to $1 \mathrm{~mL}$ of BHI, incubated for $18-24$ hours, then 100 $\mu \mathrm{L}$ was taken into $1 \mathrm{~mL}$ of BHI, incubated for 3-5 hours in an incubator. Taken $100 \mu \mathrm{L}$ of bacteria diluted with $\mathrm{NaCl} 0.9 \%$ until the turbidity is equal to the Mc Farland standard of 108 $\mathrm{CFU} / \mathrm{mLn}[13]$.

\subsection{Optimization of secondary metabolite production time}

The Mueller Hinton agar medium which had been scratched by the bacterial suspension was made of wells using a cork borer with a diameter of $6.0 \mathrm{~mm}$. Each well was filled with 50 $\mu \mathrm{L}$ of culture fluid according to the sampling sequence (day 1-14). Then stored in the refrigerator for 2 hours to accelerate the diffusion of the test culture fluid, then incubated at $37^{\circ} \mathrm{C}$ for $18-24$ hours and observed the inhibition zone diameter in the form of a clear zone around the well hole which showed the inhibitory activity of the culture fluid of Actinomycetes isolates (isolate J4) [14]. The average diameter of the inhibition zone is calculated from the 4 sides of the clear zone [15]. To observe the optimization profile of secondary metabolite production time, a curve of the relationship between the inhibition zone diameter ( $\mathrm{X}$ axis) and incubation time ( $\mathrm{Y}$ axis) was created. Optimization of the production time of secondary metabolites in isolates from the rhizosphere of Tin fruit was carried out for 14 days and the production time for secondary metabolites was obtained on day 2 [16].

\section{Results and Discussion}

The preparation culture test was carried out in a ratio (1:10) or with a concentration of $10 \%$ (v/ v) between the starter and SNB media and incubated for 5 days [9]. Stratified culture was carried out after 5 days of incubation to maintain isolate $\mathrm{J} 4$ in the log phase. As research conducted by, isolate growth entered the log phase at day 5 . The difference in the time of the growth phase is because Actinomycetes have a very varied growth time [16].

During the 14-day incubation there was a change in the color of the culture fluid as in Table 1.The color change that occurred during the incubation time showed that the Actinomycetes emitted a color pigment that was able to diffuse or not on the media [17]. This statement can indicate that the color change that occurs in the culture fluid is caused by isolate $\mathrm{J} 4$ emitting color pigments. Optimization of secondary metabolite production time aims to determine the optimal time for bacterial isolates to produce secondary metabolites so that it can be used to determine the right time to harvest secondary metabolites produced by isolate $\mathrm{J} 4$ culture fluid. The optimization test for the production time of secondary metabolites of culture fluid for these Actinomycetes isolates used the test culture fluid supernatant from day 1 to day 14 . The results of the optimization test are shown in Figures 1,2 and Table 2. 
Table 1. The results of observations of changes in the color of the test culture

\begin{tabular}{clcl}
\hline Day to- & \multicolumn{1}{c}{ Color } & Day to- & \multicolumn{1}{c}{ Color } \\
\hline $\mathbf{1}$ & clear white & $\mathbf{8}$ & Brown ++ \\
$\mathbf{2}$ & clear white & $\mathbf{9}$ & Brown +++ \\
$\mathbf{3}$ & clear white & $\mathbf{1 0}$ & Dark brown \\
$\mathbf{4}$ & Light brown & $\mathbf{1 1}$ & Dark brown ++ \\
$\mathbf{5}$ & Light brown & $\mathbf{1 2}$ & Dark brown ++ \\
$\mathbf{6}$ & Brown & $\mathbf{1 3}$ & Dark brown +++ \\
$\mathbf{7}$ & Brown + & $\mathbf{1 4}$ & Dark brown ++++ \\
\hline
\end{tabular}
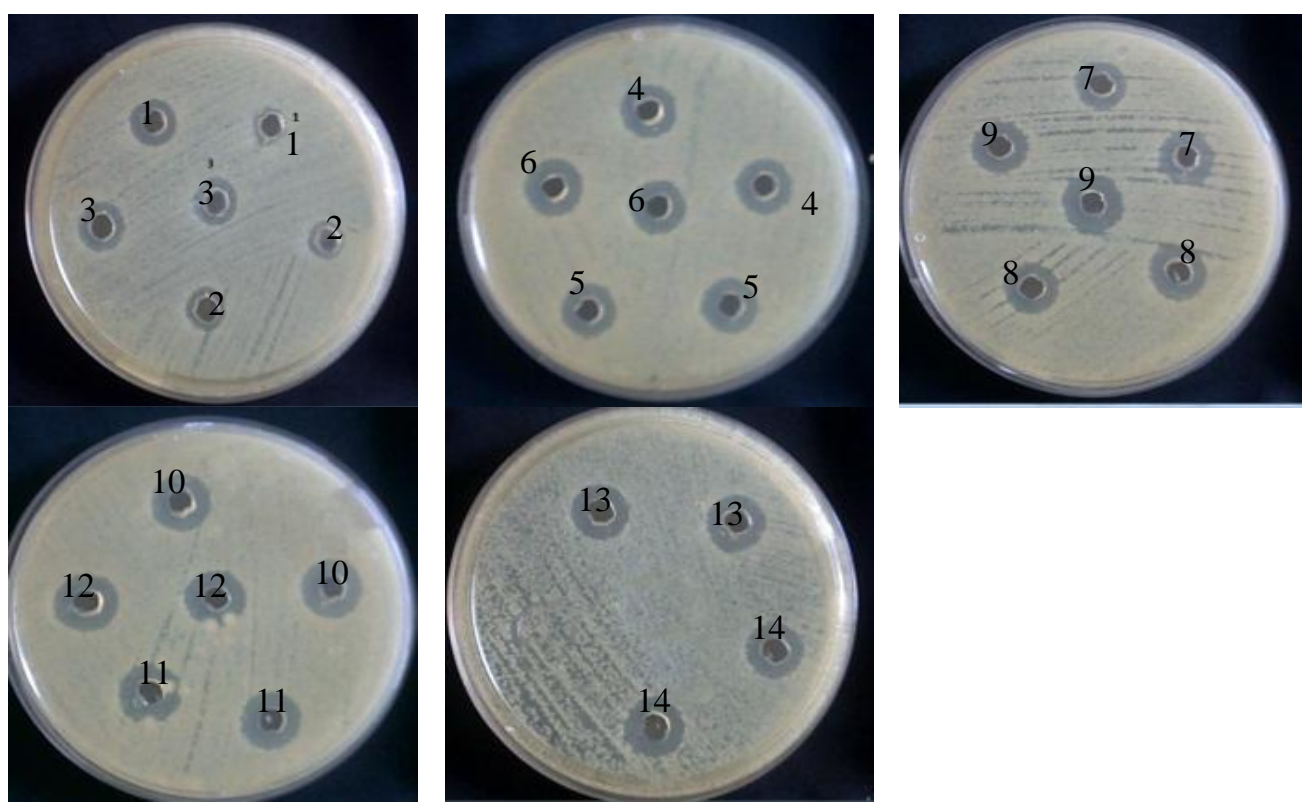

Fig. 1. Inhibition zone diameter 1-14 days against Staphylococcus aureus

Table 2. Inhibition zone diameter against Staphylococcus aureus

\begin{tabular}{|c|c|c|c|c|c|c|c|}
\hline \multirow{2}{*}{$\begin{array}{r}\mathbf{D a} \\
\mathbf{y}\end{array}$} & \multicolumn{3}{|c|}{ Inhibition zone diameter $(\mathrm{cm})$} & \multirow[t]{2}{*}{ Day } & \multicolumn{3}{|c|}{ Inhibition zone diameter $(\mathrm{cm})$} \\
\hline & 1 & 2 & Mean & & $\mathbf{1}$ & 2 & Mean \\
\hline 1 & 1,18 & 0,83 & 1,01 & 8 & 1,40 & 1,28 & 1,34 \\
\hline 2 & 1,08 & 1,10 & 1,09 & 9 & 1,33 & 1,45 & 1,39 \\
\hline 3 & 1,23 & 1,13 & 1,18 & 10 & 1,35 & 1,48 & 1,42 \\
\hline 4 & 1,35 & 1,38 & 1,37 & 11 & 1,35 & 1,40 & 1,38 \\
\hline 5 & 1,33 & 1,33 & 1,33 & 12 & 1,45 & 1,40 & 1,43 \\
\hline 6 & 1,40 & 1,28 & 1,34 & 13 & 1,35 & 1,40 & 1,38 \\
\hline 7 & 1,30 & 1,40 & 1,35 & 14 & 1,33 & 1,33 & 1,33 \\
\hline
\end{tabular}




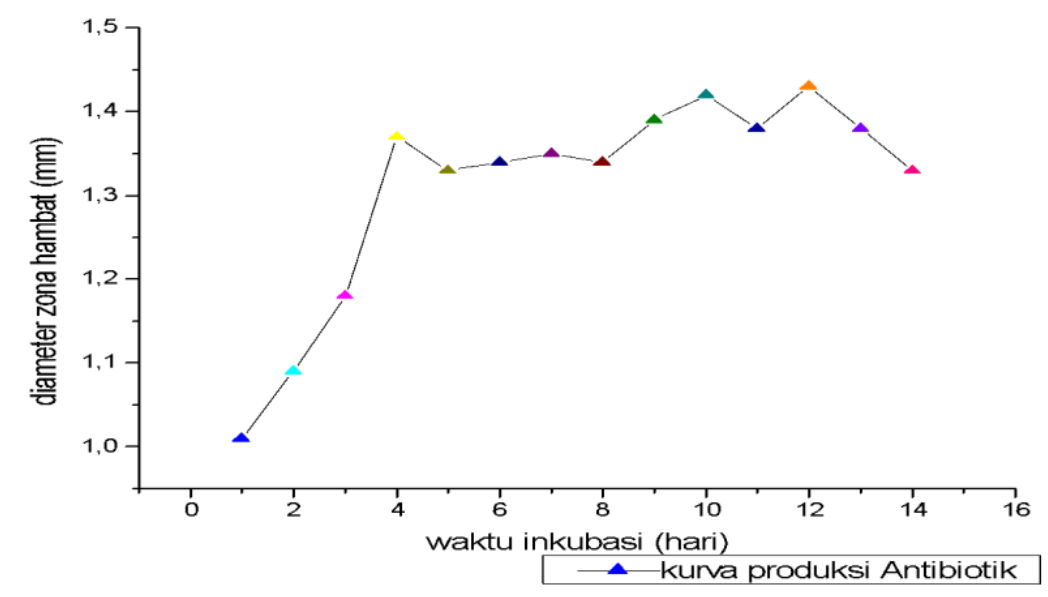

Fig. 2. Optimization profile of production time of secondary metabolites of Actinomycetes isolate culture fluid (J4 isolate) against Staphylococcus aureus

Results of inhibition zone diameter measurements from liquid culture actinomycetes isolates (isolates J4) against Staphylococcus aureus showed that secondary metabolites (antibacterials) have been produced on day 1 with a diameter of $1.01 \mathrm{~cm}$ inhibition zone. Antibacterial production will increase during the incubation period indicated by the diameter of the inhibition zone produced against the growth of Staphylococcus aureus bacteria. The production of secondary metabolites (Antibacterial) will be constant after incubation for 6 days with an inhibition zone diameter of $1.43 \mathrm{~cm}$. Antibacterial Activity constant after day 6 so as to time the harvesting of secondary metabolites (antibacterials) are potentially against Staphylococcus aureus that after incubation for 6 days shown in the chart Figure 2. Research conducted [18], shows the optimization results of secondary metabolite production time of Te234 isolate which is shown by antibacterial activity on Staphylococcus aureus bacteria after incubation on the 13th day with a diameter of $16.00 \pm 4.00 \mathrm{~mm}$. Isolate $\mathrm{J} 4$ has an optimal time that is more efficient or faster than isolate Te234 so that the time needed to produce antibacterials does not require a long time.

The results of measuring the inhibition zone diameter of the culture fluid of the Actinomycetes isolate (J4 isolate) against Eschrichia coli bacteria showed that secondary metabolites (Antibacterial) had been produced on day 1 with an inhibition zone diameter of 1.12 $\mathrm{cm}$. Antibacterial production has increased and on day 4 the production of secondary metabolites (Antibacteria) is constant with an inhibition zone diameter of $1.23 \mathrm{~cm}$. The production of secondary metabolites was constant until the 14th day of incubation, so that the optimal harvesting time of secondary metabolites (antibacterial) against Escherichia coli was after incubation for 5 days as shown in Figures 3, 4 and Table 3. The extraction time for secondary metabolites was carried out in the stationary phase. The same thing was done with the extraction of secondary metabolites carried out on the 5th day, which was entered into the stationary phase [19]. The diameter of the inhibition zone from the optimization results of the production time of secondary metabolites (Antibacterial) of the culture fluid of Actinomycetes isolates (J4 isolates) for activity testing against Staphylococcus aureus bacteria with optimal 
antibacterial potential on the 10th day with a diameter of $1.42 \mathrm{~cm}$, while against Escherichia coli bacteria on the second day -5 which is $1.23 \mathrm{~cm}$ in diameter.
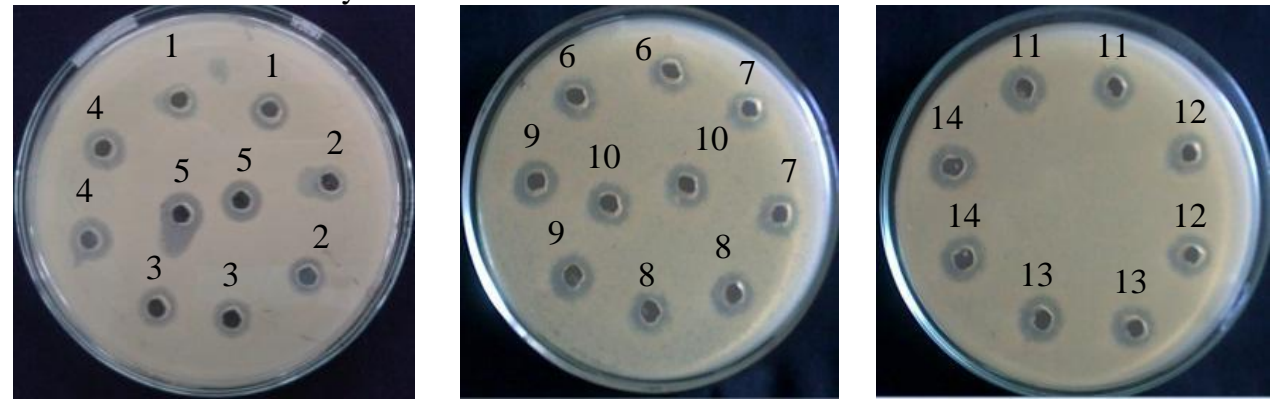

Fig. 3. Diameter of inhibition zone on day 1-14 against Escherichia coli

Table 3. Diameter of the zone of inhibition against Escherichia coli

\begin{tabular}{lcccccccc}
\hline Day & \multicolumn{2}{c}{ Inhibition zone diameter $(\mathbf{c m})$} & Day & & \multicolumn{3}{c}{ Inhibition zone diameter $(\mathbf{c m})$} \\
\cline { 2 - 3 } & $\mathbf{1}$ & $\mathbf{2}$ & Mean & & & $\mathbf{1}$ & $\mathbf{2}$ & Mean \\
\hline $\mathbf{1}$ & 1,1 & 1,13 & 1,12 & $\mathbf{8}$ & & 1,13 & 1,13 & 1,13 \\
$\mathbf{2}$ & 1,1 & 1,08 & 1,09 & $\mathbf{9}$ & & 1,15 & 1,2 & 1,18 \\
$\mathbf{3}$ & 1,03 & 1,05 & 1,04 & $\mathbf{1 0}$ & & 1,15 & 1,2 & 1,18 \\
$\mathbf{4}$ & 1,23 & 1,13 & 1,18 & $\mathbf{1 1}$ & & 1,2 & 1,15 & 1,18 \\
$\mathbf{5}$ & 1,3 & 1,15 & 1,23 & $\mathbf{1 2}$ & & 1,18 & 1,1 & 1,14 \\
$\mathbf{6}$ & 1,13 & 1,18 & 1,16 & $\mathbf{1 3}$ & & 1,18 & 1,2 & 1,19 \\
$\mathbf{7}$ & 1,13 & 1,15 & 1,14 & $\mathbf{1 4}$ & & 1,18 & 1,18 & 1,18 \\
\hline
\end{tabular}

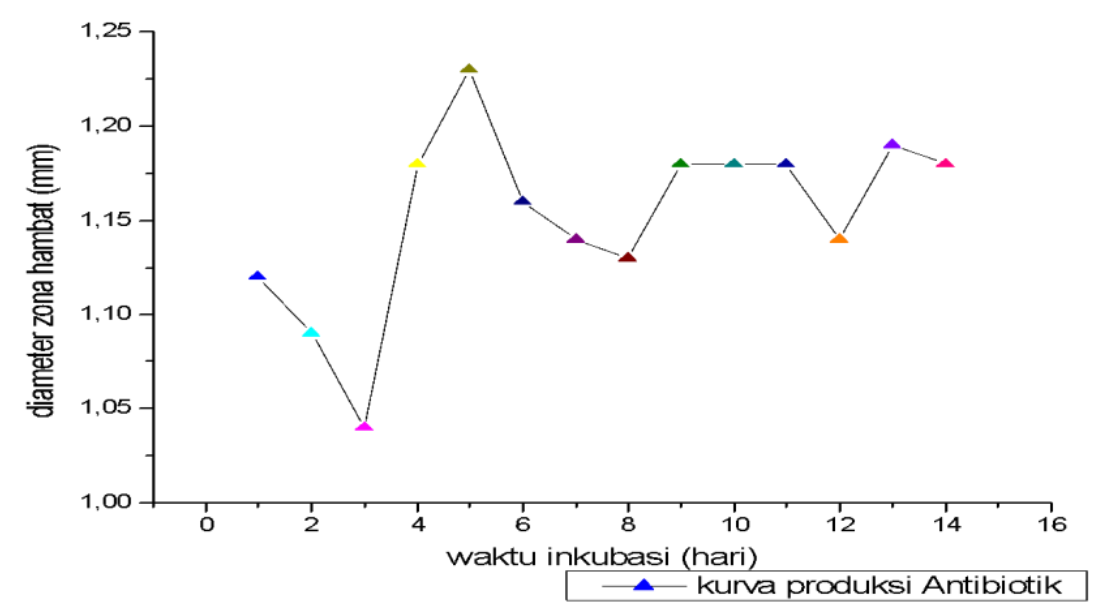

Fig. 4. Optimization profile of secondary metabolite production of Actinomycetes (J4 isolate) culture fluid against Escherichia coli bacteria 


\section{Conclusion}

The optimal production of secondary metabolites (Antibacterial) of Actinomycetes isolate (isolate J4) was based on activity tests against Staphylococcus aureus bacteria after incubation for 10 days, whereas against Escherichia coli bacteria after incubating for 5 days.

\section{References}

[1] Krüger W, Vielreicher S, Kapitan M, Jacobsen ID, Niemiec MJ (2019) Fungal-Bacterial Interactions in Health and Disease. Pathogens 8:70 . https://doi.org/10.3390/pathogens8020070Charities Aid Foundation (CAF). 2018. World Giving Index 2018 A Global View of Giving Trend

[2] Gomes TAT, Elias WP, Scaletsky ICA, Guth BEC, Rodrigues JF, Piazza RMF, Ferreira LCS, Martinez MB (2016) Diarrheagenic Escherichia coli. Braz J Microbiol 47:3-30 . https://doi.org/10.1016/j.bjm.2016.10.015

[3] Apsari PP, Budiarti S, Wahyudi AT (2019) Actinomycetes of rhizosphere soil producing antibacterial compounds against Urinary Tract Infection bacteria. Biodiversitas J Biol Divers 20: . https://doi.org/10.13057/biodiv/d200504

[4] Ayu Krishanti NPR, Zulfiana D, Wikantyoso B, Zulfitri A, Yusuf S (2018) Antimicrobial Production by an Actinomycetes Isolated from The Termite Nest. J Trop Life Sci 8:279-288 . https://doi.org/10.11594/jtls.08.03.10

[5] Warsi W, Sulistyani N (2018) The Optimization of Secondary Metabolite Production Time and Screening Antibacterial Activity of Actinomycetes Isolate from Tin Plant Rizosfer (Ficus carica). J Teknol Lab 7:15 . https://doi.org/10.29238/teknolabjournal.v7i1.120

[6] Oskay M (2011) Effects of some Environmental Conditions on Biomass and Antimicrobial Metabolite Production by Streptomyces Sp., KGG32. Int J Agric Biol 13:8Kementerian Perencanaan Pembangunan Nasional/ Badan Perencanaan Pembangunan Nasional. 2018. Masterplan Ekonomi Syariah Indonesia 2019-2024 Hasil Kajian Analisis Ekonomi Syariah di Indonesia

[7] Vijayakumar R, Panneerselvam K, Muthukumar C, Thajuddin N, Panneerselvam A, Saravanamuthu R (2012) Optimization of Antimicrobial Production by a Marine Actinomycete Streptomyces afghaniensis VPTS3-1 Isolated from Palk Strait, East Coast of India. Indian J Microbiol 52:230-239 . https://doi.org/10.1007/s12088-011-0138-x

[8] Widada J, Asmara W, Alimuddin (2011) Antifungal Production of a Strain of Actinomycetes spp Isolated from the Rhizosphere of Cajuput Plant: Selection and Detection of Exhibiting Activity Against Tested Fungi. Indones J Biotechnol 16:1-10 . https://doi.org/10.22146/ijbiotech.7829

[9] Wang X, Huang L, Kang Z, Buchenauer H, Gao X (2010) Optimization of the Fermentation Process of Actinomycete Strain Hhs.015 T. J Biomed Biotechnol 2010:1-10. https://doi.org/10.1155/2010/141876

[10] Lani MN (2014) Antimicrobial Activity of Cell Free Supernatant of Lactic Acid Bacteria Isolated from Fermented Durian Flesh against Multiple Antibiotic Resistance's Salmonella Associated with Food Poisoning Cases in Malaysia. IOSR J Pharm Biol Sci 9:60-65 . https://doi.org/10.9790/300809646065

[11] Katili AS (2017) Short Communication: Isolation of Actinomycetes from mangrove ecosystem in Torosiaje, Gorontalo, Indonesia. Biodiversitas J Biol Divers 18:826-833. https://doi.org/10.13057/biodiv/d180256

[12] Nanjwade B, Chandrashekhara S, Goudanavar P, Shamarez A, Manvi F (2010) Production of Antibiotics from Soil-Isolated Actinomycetes and Evaluation of their Antimicrobial Activities. Trop J Pharm Res 9: . https://doi.org/10.4314/tjpr.v9i4.58933

[13] Syarifuddin A, Kamal S, Yuliastuti F, Pradani MPK, Septianingrum NMAN (2019) EKSTRAKSI DAN IDENTIFIKASI METABOLIT SEKUNDER DARI ISOLAT AL6 SERTA POTENSINYA 
SEBAGAI ANTIBAKTERI TERHADAP Escherichia coli. J Bioteknol Biosains Indones JBBI 6:210 .https://doi.org/10.29122/jbbi.v6i2.3516

[14] Mustafa O, A. UT, Cem A (2004) Antibacterial activity of some actinomycetes isolated from farming soils of Turkey. Afr J Biotechnol 3:441-446. https://doi.org/10.5897/AJB2004.000-2087

[15] Parkavi V, Vignesh M, Selvakumar K, Mohamed JM, Ruby JJ (2012) Antibacterial Activity of Aerial Parts of Imperata cylindrica (L) Beauv. 4:4

[16] Hug J, Bader C, Remškar M, Cirnski K, Müller R (2018) Concepts and Methods to Access Novel Antibiotics from Actinomycetes. Antibiotics 7:44 . https://doi.org/10.3390/antibiotics7020044

[17] Putri AL, Lisdiyanti P, Kusmiati M (2018) IDENTIFIKASI AKTINOMISETES SEDIMEN AIR TAWAR MAMASA, SULAWESI BARAT DAN AKTIVITASNYA SEBAGAI ANTIBAKTERI DAN PELARUT FOSFAT. J Bioteknol Biosains Indones JBBI 5:139 https://doi.org/10.29122/jbbi.v5i2.2953

[18] Kurniawan S, Syarifuddin A, Agusta HF, Pradani MPK, Fakultas Ilmu Kesehatan, Universitas Muhammadiyah Magelang (2020) OPTIMASI PRODUKSI ANTIBAKTERI CAIRAN KULTUR ISOLAT BAKTERI (ISOLAT Te234) TERHADAP BAKTERI Escherichia coli DAN Staphylococcus aureus. J Ilm Ibnu Sina JIIS Ilmu Farm Dan Kesehat 5:211-219 . https://doi.org/10.36387/jiis.v5i2.449

[19] Cheng M-J, Tseng M, Chen I-S, Liao C-C, Yuan G-F (2009) SECONDARY METABOLITES FROM THE CULTURE BROTH OF ACTINOMYCETE ACROCARPOSPORA SP. FIRDI 001 AND THEIR ANTIMICROBIAL ACTIVITY. J Chil Chem Soc 54: . https://doi.org/10.4067/S071797072009000200024 